\title{
ANNULMENT OF MARRIAGE IN POLISH LAW AND DECLARATION OF NULLITY OF MARRIAGE IN CANON LAW - A COMPARATIVE STUDY
}

\author{
Grzegorz Bzdyrak*
}

\begin{abstract}
Annulment and nullity of marriage are two institutions that function in two separate and independent legal systems. Despite some similarities, they cannot be used interchangeably. The differences between the annulment and declaring nullity of marriage follow mainly from the fact that the canonical marriage between baptized persons is a sacrament, a lifelong and indissoluble bond. For this reason, once validly contracted, it cannot be annulled or dissolved by divorce, but only by the death of a spouse or a dispensation from an unconsummated marriage and the privilege of faith. In the case when marriage is contracted, despite the existence of impediments to marriage, the ecclesiastical tribunal, after completing the relevant proceedings, declares its nullity whereby this judgment is of a declarative nature. In the case of annulment of marriage, the legislator provided for some restriction as to the persons authorized to file a claim, and it also listed the situations in which, even though marriage was contracted in breach of law, its annulment is not possible. Therefore, convalidation by force of law is permissible. Such validation and such restrictions have not been provided by the ecclesiastical legislator, although the convalidation of marriage is possible as long as the matrimonial consent continues and some additional conditions have been satisfied. The judgment regarding the annulment of marriage is constitutive, although the effects of annulment have retroactive effects, whereby the legislator stated that for certain relationships, the rules of divorce shall be applicable.
\end{abstract}

* Assistant Lecturer in the Department of Ecclesiastical Litigation Law of the Catholic University of Lublin, al. Unii Lubelskiej 15, 20-108 Lublin, g.bzdyrak@diecezja.lublin.pl 
Both in the state and canonical orders, there are three groups of reasons that are the basis for annulment and declaration of nullity of marriage. These are impediments to marriage, defects to the declarations of intention of the spouses and defects to the mandate to contract marriage. The individual reasons have been briefly discussed to present the differences in their understanding under canon law and state law.

Key words: annulment of marriage, declaration of nullity of marriage, canonical impediments, marriage

\section{INTRODUCTION}

Marriage, which is the foundation of the family, is subject to the state laws and in the case of Catholics - also the canon law being the internal law of the Catholic Church. The family, and thus marriage as a fundamental unit of the society remains a matter of concern of both legal orders, which - while cover the same individuals forming a state and a religious community, are independent and autonomous. The autonomy and independence of the two legal orders have been guaranteed by the Constitution of the Republic of Poland of 2 April $1997^{1}$ and the Concordat of 28 July $1993^{2}$ and the Act on the relation of the State to the Catholic Church of 17 May $1989^{3}$. Due to the fact that marriage is subject to two legal orders, it is also subject to independent from each other judiciaries - and state canon ones.

Taking into consideration a significant number of disintegrating marriages, the importance of the sacrament of marriage and awareness among the faithful of their possibility to claim their rights on the canonical ground, the number of proceedings for declaring nullity of marriage

${ }^{1}$ Konstytucja Rzeczypospolitej Polskiej z dnia 2 kwietnia 1997 r. uchwalona przez Zgromadzenie Narodowe w dniu 2 kwietnia 1997 r., przyjęta przez Naród w referendum konstytucyjnym w dniu 25 maja 1997 r., podpisana przez Prezydenta Rzeczypospolitej Polskiej w dniu 16 lipca 1997 r., Dz. U. 1997 nr 78, poz. 483 ze zm.

${ }^{2}$ Konkordat między Stolicą Apostolską i Rzecząpospolitą Polską, podpisany w Warszawie dnia 28 lipca 1993 r., Dz. U. 1998 nr 51, poz. 318.

${ }^{3}$ Ustawa z dnia 17 maja 1989 r. o stosunku Państwa do Kościoła Katolickiego w Polskiej Rzeczypospolitej Ludowej, Dz. U. 1989 nr 29, poz. 154. 
conducted before ecclesiastical tribunals is increasing. Despite the fact that these proceedings become more and more popular, the knowledge of the grounds for declaring nullity is negligible. They are also mistakenly referred to as the proceedings for annulment of marriage. It should be, however, firmly stressed that canon law does not provide for the annulment of marriage, in contrast to Polish law, in which such institution is effective. In exceptional cases, Polish law also permits a claim to declare the non-existence of marriage or annulment of an act of marriage. Owing to apparent similarity of these institutions, it appears reasonable to make a comparative analysis to clarify differences between the civil annulment and the canonical declaration of nullity of marriage.

\section{CIVIL MARRIAGE VS. CANONICAL MARRIAGE}

In both legal orders the institution of marriage is defined and understood differently, but some elements are similar. Important are the differences that cause that the canonical marriage cannot be dissolved by a court judgment, and in the case of declaring nullity, marriage is deemed as null and void from the very beginning.

In Polish law there is no legal definition of marriage, but the doctrine has developed its own definitions, based on provisions of law and their interpretation made in judicial practice.

Marriage is a lasting relationship of a man and a woman, contracted in a formalized way through the declaration of intention made by both prospective spouses ${ }^{4}$. It is a legal relationship of a reciprocal nature. There are several principles that characterize marriage as an institution. First of all, marriage is a monogamous relationship of two people of the opposite sex which stays under legal protection ${ }^{5}$. It is therefore a relationship between a man and a woman, with the exclusion of other people 6 . It is also a con-

${ }^{4}$ Ustawa z dnia 25 lutego 1964 r. - Kodeks rodzinny i opiekuńczy, Dz. U. 1964 nr 9, poz. 59, dalej: KRO art. 1.

${ }^{5}$ Konstytucja art. 18.

${ }^{6} \mathrm{KRO}$ art. $13 \$ 1$. 
tinuous relationship, but in some cased provide for by law, there is a possibility to dissolve marriage, therefore it is not an unsolvable relationship. If there occurs an irretrievable and complete breakdown of marriage between the spouses, such marriage can be dissolved by divorce ${ }^{7}$. Nevertheless, this right always remains under control of the court. Separation is also permissible $^{8}$. An essential element of marriage as a legal structure is the possibility of its annulment, in strictly defined cases. It results also from the control over the legal correctness of marriage assumed by the state ${ }^{9}$. This involves another principle, which has been indicated by the doctrine, namely the principle of secularism. It is mainly about the state jurisdiction over marriage. Marriage is a contract, an agreement, a legal relationship that unites a man and a woman who jointly undertake a legal action. In the definition of marriage, M. Nazar considers it as a permanent, mutual legal relationship between a man and a woman, which can be terminated ${ }^{10}$.

It should be emphasized that marriage is a voluntary relationship, which is based on the right to its conclusion. The decisive issues are joint declarations made by the prospective spouses before a registrar, a consul, a person appointed to perform the duties of a consul or a clergyman. The wording of their declarations should be compatible, made in the simultaneous presence of the prospective spouses, in sequence one after the other ${ }^{11}$.

The canonical concept of marriage is based in the teachings of the Catholic Church and is subject to its internal law. For the Latin Church this is the Code of Canon Law of $1983^{12}$, and the Eastern Catholic Churches the Code of Canons of the Eastern Churches of $1991^{13}$. The ecclesiastical

${ }^{7} \mathrm{KRO}$ art. $56 \$ 1$.

${ }^{8} \mathrm{KRO}$ art. $611 \$ 1$.

${ }^{9}$ Kazimierz Piasecki, Wprowadzenie, In: Kodeks rodzinny i opiekuńczy. Komentarz, ed. Kazimierz Piasecki, Warszawa: LexisNexis, 2011, 16.

${ }^{10}$ Jan Mojak, Mirosław Nazar, Elżbieta Nezbecka, Zarys prawa cywilnego, Lublin: OW Verba, 2005, 511.

${ }^{11} \mathrm{KRO}$ art. $1 \$ 1$.

${ }^{12}$ Joannes Paulus II, Codex Iuris Canonici auctoritate Ioannis Pauli PP. II promulgatus (25.01.1983), AAS 75 (1983), pars II, pp. 1-317, tekst polski: Kodeks Prawa Kanonicznego, przekład polski zatwierdzony przez Konferencję Episkopatu, Poznań 1984.

${ }^{13}$ Joannes Paulus II, Codex Canonum Ecclesiarum Orientalium auctoritate Ioannis Pauli PP. II promulgatus, AAS 82 (1990), pp. 1033-1363; tekst polski: Kodeks Kanonów Kościołów Wschodnich, Lublin 2002. 
legislator provides a definition of marriage, indicating that it is a covenant between a man and a woman, by which they establish between themselves a partnership of the whole life and which is ordered by its nature to the good of the spouses and their offspring. For the baptized persons, it has been raised by Jesus Christ to the dignity of a sacrament ${ }^{14}$. Marriage is formed by the matrimonial consent declared, according to the law, by the prospective spouses who are capable of its declaration. With this act of intention, the spouses irrevocably and mutually give and accept themselves each other in order to form a family ${ }^{15}$. Therefore, attention should be paid to personal and religious character of the canonical marriage. Similarly to the civil marriage, it is a monogamous relationship. In the case of the canonical marriage, unity and indissolubility are important factors, which in the case of marriage between two baptized persons acquire a special power by virtue of the sacrament ${ }^{16}$. The canonical marriage, as opposed to the civil marriage, is not only durable, but lifelong and therefore not subject to termination under an agreement between the parties or a court decision and despite cessation of the civil marriage, the marriage covenant within the canonical meaning remains in force and effect between the spouses. Canonical marriages can only be terminated by death of one of the spouses or in case of dispensation granted by the Holy See from a marriage contracted and not consummated, and in the case of the privilege of faith.

\section{JURISDICTION OVER MARRIAGE IN POLAND}

Marriage, as an institution that combines in one person two legal orders - state and religious ones, is also subject to two jurisdictions. Since marriage has been raised to the status of a sacrament, marriage belongs to the public good of the Church and is subject to its exclusive jurisdiction.

${ }^{14}$ Can. $1055 \$ 1$; CCEO can. $776 \$ 1-2$; Wojciech Góralski, Studia nad matżeństwem i rodzina, Warszawa: Wydawnictwo UKSW, 2007, 50.

${ }^{15}$ Can. 1057; CCEO can. $776 \$ 1$, can. $817 \$ 1-2$.

${ }^{16}$ Can. 1056; CCEO can. $776 \$ 3$. 
As far as the purely civil effects of marriage are concerned, the legislator has referred this issue directly to the resolutions of the state authorities ${ }^{17}$. As the two legal systems are independent and autonomous, which is reflected in the Constitution and the Concordat of $1993^{18}$, also jurisdiction in matrimonial matters of each authority is independent and, what is important, exclusive ${ }^{19}$. The importance of the judicial authority of the Catholic Church over marriage was confirmed by the relevant provisions in the Constitution and the Concordat of 1993. It was directly guaranteed that in proceedings for declaring nullity of marriage and other matrimonial issues, the exclusive jurisdiction was vested to the competent ecclesiastical authority. Issuance of judicial decisions with civil effects belongs to the exclusive jurisdiction of the state courts ${ }^{20}$. The State respects the independence of the Catholic Church in its jurisdiction over marriage, the Church recognizes the state authority over civil marriage, taking into account the autonomy and independence of each community in its own field. The matrimonial procedures pending before the ecclesiastical tribunals are conducted based on separate regulations, and their judgments produce effects only on the canonical forum. Judicial decisions made before the state courts have no influence on the existence of the canonical marriage. From the principle of autonomy and independence also results the lack of mutual recognition of judgments by the state courts and ecclesiastical tribunals ${ }^{21}$ and the lack of possibilities for mutual notification of rulings issued in matrimonial matters. This follows directly from the provision of the Concordat of 1993, separating the powers of the ecclesiastical tribunals and the state courts. Even canonical marriages with civil effects, upon their entry into the records of the registry office, are subject to two independent jurisdictions ${ }^{22}$. Decisions regarding marriage issued by the state or ecclesiastical authorities will produce effects only on their relevant forum. It

${ }^{17}$ Can. 1059; CCEO can. $780 \$ 1$.

${ }^{18}$ Konstytucja RP art. 25 ust.3; Konkordat art.1.

${ }^{19}$ Konkordat art. 10 ust. 3-4.

${ }^{20}$ Konkordat art. 10 ust. 3-4.

${ }^{21}$ A difference situation is e.g. in Portugal or Italy.

22 Por. Adam Bartczak, Sądowa jurysdykcja nad matżeństwem w Polsce, Łódzkie Studia Teologiczne 23 (2014) n 2: 27-38. 
should be noted, however, that the Concordat allows for some possibility for the notification of ecclesiastical judgments in matrimonial matter ${ }^{23}$.

\section{CIVIL ANNULMENT OF MARRIAGE - REASONS AND CONSEQUENCES}

The annulment of marriage may have a dual structure. The Act may provide that marriage which was contracted contrary to a specific prohibition shall be ex lege null and void. In such case, the court's judgment in this matter is merely declaratory, and thus confirms certain existing legal status. In the second structure, marriage is valid even if it was contracted contrary to the prohibition, but is voidable at the request of the authorized person. The judgment is therefore constitutive, and by the time of it becomes final, marriage is considered as valid and protected.

The Polish legal system does not provide for nullity of marriage by force of law, and for the annulment of marriage a court decision issued in the court proceedings is necessary, since it concerns the matters of matrimonial status.

The annulment of marriage can only follow for the reasons strictly defined by $\mathrm{law}^{24}$. The reasons for annulment specified by the legislator can be divided into three groups: canonical impediments, defects in the declaration of intention and the shortcomings of mandate granted to contract marriage ${ }^{25}$.

The circumstances which exclude the contracting of marriage were specified by the legislator in Art. 10-15 of the Family and Guardianship Code and include: lack of required age, total incapacitation, mental illness or mental retardation, bigamy, kinship, affinity, adoption. These impediments are the reason for the annulment of marriage. A claim for annulment of marriage, depending on the reason which is the basis for the claim, may

${ }^{23}$ Konkordat art. 10 ust. 5.

${ }^{24} \mathrm{KRO}$ art. 17.

25 Jerzy Ignatowicz, Mirosław Nazar, Prawo rodzinne, Warszawa: LexisNexis, 2010, 232. 
be filed by the spouses, by the public prosecutor ${ }^{26}$ and any person who has a legal interest ${ }^{27}$. In some circumstances, the subjective mandate is subject to certain limitations.

The impediment, mentioned as first by the legislator is the lack of required age. Under the currently applicable laws, the minimum age for the prospective spouses is 18 years. For important reasons, however, the guardianship court may permit the marriage of a woman over 16 years if the circumstances indicate that it would be in the best interests of the newly founded family ${ }^{28}$. As a result of the contracted marriage, a minor obtains majority and shall not lose it, even if marriage is annulled ${ }^{29}$.

Failure to observe the required age is a ground for the annulment of marriage. The annulment of marriage can be requested even if the family court permitted it, but the woman entered it before the age of 16 . The request for the annulment of marriage cannot be, however, always requested on the ground of the lack of the required age. The spouses ${ }^{30}$ and the public prosecutor are authorized to file the claim. However, marriage cannot be annulled on the ground of lack of the required age, if the spouse was over 18 years before the claim was filed with the court. Upon the achievement of the prescribed age, marriage becomes convalidated. When a woman who contracted marriage without the proper age or without the consent of the family court, becomes pregnant, her husband cannot file a claim for the annulment of marriage. In such case the woman is the only authorized person ${ }^{31}$.

The second reason for the annulment of marriage is complete incapacitation of one of the prospective spouses. As in the case of the age limitation, the claim may be filed by the spouses and the public prosecutor, however if the incapacitation is repealed, marriage becomes convalidat$\mathrm{ed}^{32}$. It should be emphasized that the impediment is the complete legal

${ }^{26} \mathrm{KRO}$ art. 22.

${ }^{27} \mathrm{KRO}$ art. 22.

${ }^{28} \mathrm{KRO}$ art. 22.

${ }^{29}$ Ustawa z dnia 23 kwietnia 1964 r. - Kodeks cywilny, Dz.U. 1964 nr 16, poz. 93; dalej KC, art. $10 \$ 2$.

${ }^{30} \mathrm{KRO}$ art. $10 \$ 2$.

${ }^{31} \mathrm{KRO}$ art. $10 \$ 4$.

${ }^{32} \mathrm{KRO}$ art. 11. 
incapacitation only, which means that marriage can be validly contracted by a partially incapacitated person. A similar situation is in the case of an mental illness or mental retardation, however if the illness or retardation causes no risk to marriage or health of the future offspring, and the prospective spouse is not totally incapacitated, the court may permit the contracting of marriage ${ }^{33}$. Not every illness or mental retardation may be the reason for the annulment of marriage. It is about the condition that causes a risk to marriage or health of the offspring. Equally important is the moment when the disease occurs, because the impediment of mental illness or retardation, which occurred at the time of contracting marriage and did not cease before a claim was filed with the court. It is therefore necessary that the disease is clearly identified. Remission is synonymous with mental illness, if in a particular case it is temporary and lasts for a short term. Termination of the disease is construed as its expiry, and not only disappearance of acute symptoms ${ }^{34}$.

Another circumstance which constitutes a ground for the annulment of marriage is bigamy, i.e. staying married ${ }^{35}$. It is one of the oldest impediments, as it already existed in Roman law. This is due to the fact that monogamy of marriage is universal and is present in the majority of legal systems ${ }^{36}$. It is important for this impediment to determine the duration of the marriage contracted by the bigamous spouse. Marriage begins upon its contracting by way of submitting declarations of intention, in a prescribed manner, and is terminated upon its annulment or termination. A request for the annulment of marriage due to bigamy may be filed, in addition to the spouses and the public prosecutor, by any person who has a legal interest. Undoubtedly, the spouse from the previous marriage will have a legal interest, as well as children from that relationship. No special circumstances of the case, that would be comparable to the good of the bigamous spouses or their interest have any importance for the establishment of legal

${ }^{33} \mathrm{KRO}$ art. 12 .

${ }^{34}$ Krystyna Gromek, Kodeks rodzinny i opiekunczy. Komentarz, Warszawa: C.H. Beck, 2016, 63-65.

${ }^{35} \mathrm{KRO}$ art. 13.

${ }^{36}$ Jan Winiarz, Janusz Gajda, Prawo rodzinne, Warszawa: LexisNexis, 2001, 50-55. 
interest ${ }^{37}$. The special importance of the prohibition of bigamy should be noted, because in addition to the civil - family sanction, Polish law provides for criminal penalty for its violation ${ }^{38}$.

The legislator also anticipated an impediment to marriage related to family links between the prospective spouses. Relatives with the lineal consanguinity, siblings or relatives by affinity in the direct line cannot contract marriage with each other. In the case of relatives by affinity, this prohibition is not absolute because the court may allow such marriage for important reasons. Although the criminal law, like in the case of bigamy, provides for no penalty for breach of the ban in question, it is a prohibited act to undertake conjugal life with an ascendant, descendant or a sibling ${ }^{39}$.

The legislator also introduced a prohibition of marriage if the prospective spouses stay in the relationship of adoption ${ }^{40}$. This is because the relationship of adoption is formed between the adoptee and the adopter just like the relationship between the child and its parents, however adoption is not a consequence of the legal event of birth but the court's decision ${ }^{41}$. The spouses and the public prosecutor may request the annulment of marriage, unless the adoption relationship has ceased ${ }^{42}$. However, this will not apply to the total adoption, because it cannot be terminated ${ }^{43}$.

Another group of reasons on which are the ground for the annulment of marriage are defects in the declarations of intention made by spouses to get married, which the legislator listed in Art. $15^{1}$ of the Family and Guardianship Code. It applies to the defects in the declaration of intention, which are provided for by the Civil Code, except for simulation, therefore the condition that excludes making a conscious and free decision

${ }^{37}$ Radosław Krajewski, Bigamia $w$ prawie polskim i w prawie kanonicznym, Włocławek: Włocławskie Wydawnictwo Diecezjalne, 2003, 24-25.

${ }^{38}$ Ustawa z dnia 6 czerwca 1997 r. - Kodeks karny, Dz. U. 1997, nr 88, poz. 553, dalej KK art. 206, por. Zdzisław Jancewicz, Przestępstwo z artykutu 206 kk na tle wybranych zagadnień związanych z matżenstwem bigamicznym, Kościelne Prawo Procesowe. Prawo Rodzinne. Materiały i Studia t. IV, 61-81.

${ }^{39} \mathrm{KK}$ art. 201.

${ }^{40} \mathrm{KRO}$ art. 15.

${ }^{41} \mathrm{KRO}$ art. 121; por. Andrzej Stelmachowski, Przysposobienie w polskim prawie rodzinnym, Warszawa: Wydawnictwo Prawnicze, 1957, 92.

${ }^{42} \mathrm{KRO}$ art. $15 \$ 2-\$ 3$.

${ }^{43} \mathrm{KRO}$ art. $125^{1}$. 
and its declaration, confusion, deceit, distortion by a messenger and an unlawful threat ${ }^{44}$. The spouses declaring their intention to contract marriage should be aware of the decision taken and be free to express it, which means that they do it with full knowledge of the content of their declaration, as well as its effects ${ }^{45}$. The legislator has, however, limited the right to file a claim for the annulment of marriage, indicating that the claim may be filed only by the spouse who makes such defective declaration of intention. Certainly, this right shall also be available to the public prosecutor. There has been also introduced a time limit, when the annulment of marriage can be requested on the ground of these defects. After six months from the cessation of the condition excluding the conscious declaration of the intention, discovery of an error or cessation of the concern caused by the threat, and in any event three years form the date of contracting marriage, it becomes convalidated ${ }^{46}$.

Since the legislator permits under certain conditions a possibility to contract marriage by proxy ${ }^{47}$, the last group of reasons for annulment of marriage are deficiencies in the mandate. When analyzing Art. 6 of the Family and Guardianship Code, the general provisions applying to the authorization should be kept in mind, however with respect to the specific character of the legal action which is the contracting of marriage. There are identified three types of defects related to the mandate: no court permission to contract marriage by proxy, invalidity of the mandate and effective revocation of the mandate.

All these circumstances cause that the proxy acts invalidly, and therefore also it cannot validly make a declaration of intention for and on behalf of his principal ${ }^{48}$.

When declaring the annulment of marriage, the court decides also whether and which of the spouses entered into marriage in bad faith, that

${ }^{44} \mathrm{KC}$ art. 82, art. 84-87.

${ }^{45}$ Krystyna Gromek, Kodeks rodzinny i opiekunczy. Komentarz, Warszawa: C.H. Beck, 2016, 86.

${ }^{46} \mathrm{KRO}$ art. $15^{1} \$ 3$.

${ }^{47} \mathrm{KRO}$ art. 6.

${ }^{48}$ See: Zdzisław Jancewicz, Instytucja unieważnienia matżeństwa w prawie polskim, Stalowa Wola: Drukarnia Diecezjalna w Sandomierzu, 2008, 128-140. 
is at the time of contracting marriage he/she knew of the circumstance which are the reason for its annulment ${ }^{49}$.

As it has already been stated, the Polish legislator has no knowledge of nullity of marriage by force of law, therefore the issued decision to annul marriage is constitutive. However, this is a special constitutiveness, therefore the decision works backwards, i.e. ex tunc. This means that marriage is considered to have not been contracted. The consequence of the above is, inter alia, cessation of affinity and the spouse who changed his/her surname by marriage, returns to its previous surname ${ }^{50}$. There are some exceptions as to the consequences of the annulment. The legislator indicated that in the issues pertaining to joint children and property relations, the relevant provisions concerning divorce shall be applicable, and the spouse who entered into marriage in bad faith is treated as the spouse guilty of the marriage breakdown, which is particularly important for determination of the obligation to provide maintenance to the innocent spouse $\mathrm{e}^{51}$. Therefore, the court decides on parental authority over minor children, place of their residence, contacts between the parents and the child, the obligation to provide maintenance to children as well as to the spouse, method of use of the common house and in some cases also on the division of property assets $^{52}$.

As it has already been indicated, in some cases strictly stipulated by law, marriage is validated, i.e. convalidated despite the occurrence of impediments to marriage. This means that marriage is valid and thus its annulment cannot be requested, which does not prevent its dissolution by divorce. What is important, unlike the validation in canon law, it is not important whether the couple still lives together in harmony or not.

Declaring the annulment of marriage must be distinguished from the annulment of an act of marriage and the non-existence of marriage. The annulment of an act marriage applies to the situations when the declarations for contracting marriage have not made at all, but still the certificate

${ }^{49} \mathrm{KRO}$ art. 20.

50 Jerzy Ignatowicz, Mirosław Nazar, Prawo rodzinne, Warszawa: LexisNexis, 2010, 235-236.

${ }^{51} \mathrm{KRO}$ art. 21.

${ }^{52} \mathrm{KRO}$ art. 58. 
of marriage has been drawn up. In such case, the annulment of the civil act of marriage can be claimed under non-procedural proceedings, because it is inconsistent with the truth. However, if the prospective spouses want to make a declaration of contracting marriage, but the conditions laid down in Art. 1 of the Family and Guardianship Code have not be observed, such marriage is deemed as non- existent at all (matrimonium non existense). If the marriage certificate has been drawn up, any persons who has a legal interest may request that the declaration of non-existence of marriage under the relevant proceedings ${ }^{53}$. It should also be noted that the problem of the existence or non-existence of marriage occurs when marriage has been contracted before an improperly appointed registrar or before other unauthorized person. The court decision on declaring the existence or non-existence of marriage is declarative in nature, since it neither creates a legal relationship nor repeals it, because the matrimonial relationship either exist or is non-existent ${ }^{54}$.

\section{NULLITY OF THE CANONICAL MARRIAGE - REASONS AND CONSEQUENCES}

A consequence of indissolubility of the sacramental marriage is than once validly contracted, it cannot be dissolved by divorce or even annulled. The matrimonial bond can be dissolved only for a good reason, but only in the case of the marriage that has been contracted but unconsummated or under the privilege of faith.

The canon law allows, however, that nullity of marriage is declared. Nullity of marriage means that from the very beginning, due to certain reasons, the matrimonial bond did not exist. Marriage is null and void from the very beginning, and this is confirmed by a final judgment issued

${ }^{53} \mathrm{KRO}$ art. 2: Jeżeli mimo niezachowania przepisów artykułu poprzedzającego został sporządzony akt małżeństwa, każdy kto ma w tym interes prawny, może wystąpić z powództwem o ustalenie nieistnienia małżeństwa.

${ }^{54}$ Jerzy Ignatowicz, Mirosław Nazar, Prawo rodzinne, Warszawa: LexisNexis, 2010, 230-231. 
by the ecclesiastical tribunal. This judgment, in contrast to the judgment on annulment, is merely declarative and confirms the fact that marriage was invalidly contracted by the prospective spouses. However, by the time such judgment is issued, even if in doubt, marriage is considered as valid because it will benefit only from the favor of law ${ }^{55}$.

Marriage may be contracted by all persons who are not prohibited by $\mathrm{law}^{56}$. Hence, there are certain restrictions which are called impediments to marriage ${ }^{57}$. The impediments to marriage are the circumstances that exclude certain persons from contracting marriage, and so they render them unqualified to contract marriage validly ${ }^{58}$. Another legal reason for declaring nullity of marriage is a defective matrimonial consent and absence of the prescribed canonical form. It should be noted that in addition to the impediments to marriage, the ecclesiastical legislator provides for certain other prohibitions on marriage, but their breach shall not annul marriage, but only make it ignoble ${ }^{59}$. The ecclesiastical legislator, when defining impediments to marriage that come from the divine natural law or the positive law and the ecclesiastical law, had in mind the good of the institution of marriage as a sacrament and the good of the matrimonial community. Therefore, bearing the aforementioned good in mind, it is possible to dispense from some impediments to marriage, after specifying the reasons that support its granting.

In contrast to the civil marriage, the right to challenge the canonical marriage on the ground of its nullity is available to the spouses and the promoter of justice ${ }^{60}$. By way of exception, after one or both spouses decease, the validity of marriage may be contested by another person who has a legal interest ${ }^{61}$.

55 Can. 1060; CCEO can. 779.

${ }^{56}$ Can. 1060; CCEO can. 778.

${ }^{57}$ Cyprian Suchocki, Przeszkody matżeńskie w prawie kanonicznym i polskim kodeksie rodzinnym i opiekuńczym, Lublin-Sandomierz: Wydawnictwo Diecezjalne, 1997, 15.

${ }^{58}$ Janusz Gręźlikowski, Przeszkody matżeńskie wynikające z węzta religijnego, Prawo Kanoniczne 55 (2012) 2:74.

${ }^{59}$ Can. $1077 \$ 1$, can. 1124, can. 1682; CCEO can. $794 \$ 2$, can. 813, can. 1368.

${ }^{60}$ Can. $1674 \$ 1$; CCEO can. 1360.

${ }^{61}$ Can. $1674 \$ 2$; CCEO can. 1361. 
The first impediment to marriage indicated by the legislator is the impediment of age. A man, who has not attained the age of 16 years and a woman who has not attained the age of 14 years cannot enter into a valid marriage, however the conference of bishops of the given country is free to set a higher age for the licit celebration of marriage ${ }^{62}$. The point is that the prospective spouses are mature enough to presume that they have a minimum knowledge about marriage ${ }^{63}$. This is an absolute prohibition and its violation causes the nullity of marriage. In contrast to the civil marriage, attainment by the spouse of the prescribed age does not result in the validation of marriage. The simple or radical sanation of marriage contracted contrary to the impediment of age is necessary ${ }^{64}$.

Another impediment to marriage is the impediment of impotence, i.e. sexual impotence. Anyone who is unable to perform a conjugal act may not contract marriage. This inability may involve both a woman and a man, but it must be antecedent and perpetual ${ }^{65}$. Since this impediment comes from the natural law of God, therefore no dispensation from it can be granted ${ }^{66}$. The Polish law provides for no such impediment.

The ecclesiastical legislator also provided for an impediment of disparity of cult, which occurs between a person baptized in the Catholic Church or accepted to it and an unbaptized person. Due to the ecclesiastical origin of this impediment, it can be dispensed from after prior fulfillment of the conditions required by law ${ }^{67}$. This impediment also ceases in the case of the spouse being baptized.

The next impediment is the impediment of religious profession, also referred to as the impediment of the public vow of chastity. Anyone bound by the public perpetual vow of chastity in a religious institute who

${ }^{62}$ Can. 1083; CCEO can. 800. Konferencja Episkopatu Polski ustaliła, iż przepisanym wiekiem dla zawarcia małżeństwa zarówno dla kobiety jak i mężczyzny jest 18 lat.

${ }^{63}$ Can. $1096 \$ 2$; CCEO can. 819.

${ }^{64}$ Ginter Dzierżoń, Przeszkoda wieku, In: Przeszkody małżeńskie w prawie kanonicznym, ed. Wojciech Góralski, Warszawa: Wydawnictwo UKSW, 2016, 81-82.

${ }^{65}$ Can.1094; CCEO can.802.

${ }^{66}$ See: Henryk Stawniak, Przeszkoda niemocy ptciowej, In: Przeszkody małżeńskie w prawie kanonicznym, ed. Wojciech Góralski, Warszawa: Wydawnictwo UKSW, 2016, 91-156.

${ }^{67}$ Can. $1086 \$ 1-2$; CCEO can. 803. 
attempts to contract marriage, makes it invalidly ${ }^{68}$. Similarly, the adoption of priestly ordination by a man is also an impediment ${ }^{69}$. This prohibition covers a priest as well as a married deacon who cannot contract another marriage, e.g. in the event of widowhood. The dispensation from both impediments has been reserved for the Holy See ${ }^{70}$. These impediments are also non-existent in Polish law.

Another impediment, unknown to Polish law, introduced by the ecclesiastical legislator is the impediment of abduction. No marriage can be validly contracted between a man and a woman who has been abducted or at least detained with a view of contracting marriage. It does not apply to the situation in which after the woman has been separated from the captor and established in a safe and free place, chooses marriage of her own accord $^{71}$. It's important, there is no impediment if a woman abducts or detains a man. The perpetrator of the act should be a man who the woman is to marry, and not a third party, although it is not necessary that the man acts alone. The ratio legis of this impediment follows from the need to protect the freedom of an individual to contract marriage ${ }^{72}$. A slightly wider range of impediments is provided for by the Code of Canons of the Eastern Churches, which states that the "abducted person" which means that the impediment also applies to abduction or detention of $\operatorname{man}^{73}$.

The ecclesiastical legislator also prohibits that marriage is contracted by the persons who has brought about the death of a spouse with the intention to marry another person. What is important, physical or moral cooperation to the death of a spouse is also an impediment ${ }^{74}$. It is a so

${ }^{68}$ Can. 1088; CCEO can. 805.

${ }^{69}$ Can. 1087; CCEO can. 804.

${ }^{70}$ Sylwester Kasprzyk, Unieważnienie matżeństwa w polskim prawie rodzinnym a stwierdzenie nieważności matżeństwa w prawie kanonicznym, In: Iustitia Civitatis Fundamentum. Księga pamiątkowa ku czci Profesora Wiesława Chrzanowskiego, ed. Henryk Cioch, ks. Antoni Dębiński, Jacek Chaciński, Lublin: Towarzystwo Naukowe KUL, 2003, 545.

${ }^{71}$ Can.1089.

${ }^{72}$ Ginter Dzierżon, Przeszkoda uprowadzenia (kan. 1089 KPK), In: Matrimonium spes mundi. Małżeństwo i rodzina w prawie kanonicznym, polskim i międzynarodowym, ed. Tadeusz Płoski, Justyna Krzywkowska, Olsztyn: Wydawnictwo UWM, 2008, 133-142.

${ }^{73} \mathrm{CCEO}$ can. 806.

${ }^{74}$ Can. 1090; CCEO can. 807. 
called the impediment of crime ${ }^{75}$. The introduction of this impediment safeguards human life. Because this impediment follows from the ecclesiastical law, it can be dispensed but the Holy See does it very rarely.

Similarly to Polish law, marriage contracted between the relatives in the direct line, and in the collateral line up to the fourth degree of consanguinity, inclusive, is prohibited in canon law, although dispensation can be granted to the prospective spouses who are relatives in the collateral line from the third degree ${ }^{76}$. A marriage contracted between affinities in the direct line shall also not be valid, however dispensation can be granted in this respect ${ }^{77}$. The Code of Canons of the Eastern Churches also extends this impediment to the affinities in the collateral line to the second degree $^{78}$.

An impediment which is absent in Polish law is also the impediment of public decency, which arises from an invalid marriage after the commencement of conjugal life or notorious or public concubinage. The legislator has, however, restricted the prohibition of contracting marriage in the first degree of the direct line between a man and relatives of a woman and vice versa ${ }^{79}$. Also this impediment can be dispensed from.

The last impediment to marriage provided for in the Code of Canon Law, which is the equivalent of the impediment of adoption, is the impediment of legal consanguinity, i.e. adoption. The prohibition covers the persons related by legal consanguinity in the direct line or the second degree in the collateral line ${ }^{80}$.

The Code of Canons of the Eastern Churches provides for another impediment which does not exist in law of the Latin Church or Polish law. Namely, the impediment of spiritual kinship that comes from baptism and takes place between a godfather and a baptized person, and his/her parents. These people cannot enter into a valid marriage with each other ${ }^{81}$.

${ }^{75}$ Ginter Dzierżoń, Przeszkoda występku (kan. 1090 \$1-2 KPK), Ius Matrimoniale 11/17 (2006):79.

${ }^{76}$ Can. 1091; CCEO can. 808.

77 Can. 1092.

${ }^{78}$ CCEO can. 809.

${ }^{79}$ Can. 1093; CCEO can. 810.

${ }^{80}$ Can. 1094; CCEO can. 812.

${ }^{81}$ CCEO can. 811. 
Just as in Polish law, the basis for declaration of nullity of marriage in canon law are defects of the matrimonial consent. The legislator has provided for the following defects: ignorance of the nature of marriage ${ }^{82}$, a defect of reason ${ }^{83}$, an error, including an error concerning the person ${ }^{84}$, an error concerning the quality of the person ${ }^{85}$, an error concerning the unity or indissolubility or the sacramental dignity of marriage ${ }^{86}$, deceit concerning the quality of the other party ${ }^{87}$, simulation ${ }^{88}$, conditioned consent ${ }^{89}$ and force or grave fear ${ }^{90}$. Therefore, the ones who lack the sufficient use of reason because of a mental illness or mental retardation, who are therefore not able to comprehend the nature of marriage, cannot contract marriage. Moreover, the marriage contracted between the people, where at least one has a grave defect of the discretion of judgment concerning the essential matrimonial rights and duties to be mutually given and accepted, or because of psychic incapacity, is not able to undertake and fulfill those obligations ${ }^{91}$. The matrimonial consent may be subject to an error concerning the person or its essential quality, but only if this quality was directly and principally intended. Deceptive confusion must relate to the circumstances that can seriously disrupt the matrimonial community to be considered the reason for declaring nullity of marriage. The issuance of a simulated consent may cause nullity of marriage, with simultaneous exclusion of marriage itself or its essential quality. The defect concerning the matrimonial consent involves making it subject to a condition about

${ }^{82}$ Can. 1096; CCEO can. 819.

${ }^{83}$ Can. 1095; CCEO can. 818.

${ }^{84}$ Can. $1097 \$ 1$; CCEO can. $820 \$ 1$.

${ }^{85}$ Can. $1097 \$ 2$; CCEO can. $820 \$ 2$.

${ }^{86}$ Can. 1099; CCEO can. 822.

${ }^{87}$ Can. 1098; CCEO can. 821.

${ }^{88}$ Can. $1101 \$ 2$; CCEO can. $824 \$ 2$.

${ }^{89}$ Can. 1102; CCEO can. 837.

${ }^{90}$ Can. 1103; CCEO can. 825.

${ }^{91}$ See: Stanisław Paździor, Przyczyny psychiczne niezdolności osoby do zawarcia matżeństwa w świetle kan. 1095 n.3, Lublin: Wydawnictwo KUL, 2009; Stanisław Paździor, Przyczyny poważnego braku rozeznania oceniającego w świetle kan. 1095 n. 2, Lublin: Polihymnia, 2004. 
the future. Also, fear or force will result in declaring nullity of the expressed matrimonial consensus ${ }^{92}$.

Since the ecclesiastical legislator also allows for the possibility to contract the canonical marriage by proxy, the reason for declaring nullity may be the defects in the mandate. A special mandate to contract marriage with a person is required for valid contracting of marriage and it is important that the principal choses the proxy by himself and the proxy personally performs his task. The mandate must be signed not only by the principal, but also by a parish priest or an ordinary of the place where the mandate has been issued, or by a priest delegated by either of them or at least by two witnesses, unless it is made in the form of an authentic document, according to the requirements of the state law. If the principal cancels the mandate or becomes mentally ill before the marriage was contracted, the sacrament will be invalid even if the proxy or the other party were not aware of $\mathrm{it}^{93}$.

The last reason for declaring nullity of marriage is failure to observe the legal form upon its contracting. The ecclesiastical legislator has provided for two forms for contracting marriage - ordinary ${ }^{94}$ and extraordinary one, which applies in the case of risk of death or when it is reasonably anticipated that the person competent to assist upon the contracting of marriage is not available or can be reached only with significant inconvenience, and such condition will continue at least for a period of one month ${ }^{95}$.

As in the case of the civil marriage, it is possible to validate the canonical marriage. The convalidation of marriage is an act in law by which an invalidly contracted marriage becomes canonically valid, with the possibility of its convalidation being conditioned by the reason of nullity of marriage ${ }^{96}$.

92 Sylwester Kasprzyk, Unieważnienie matżenstwa w polskim prawie rodzinnym a stwierdzenie nieważności matżeństwa w prawie kanonicznym, In: Iustitia Civitatis Fundamentum. Księga pamiątkowa ku czci Profesora Wiesława Chrzanowskiego, ed. Henryk Cioch, ks. Antoni Dębiński, Jacek Chaciński, Lublin: Towarzystwo Naukowe KUL, 2003, 549.

${ }^{93}$ Can. 1105 ; CCEO can. $837 \$ 2$.

${ }^{94}$ Can. 1108-1112; CCEO can. 828-830.

${ }^{95}$ Can. $1116 \$ 1$ pkt. 2; CCEO can. 832.

${ }^{96}$ Wojciech Góralski, Kościelne prawo matżeńskie, Warszawa: Wydawnictwo UKSW, 2006, 349. 
The legislator provides for two types of convalidation - the simple one, which requires the removal of the impediment that causes the nullity of marriage and a renewed exchange of the matrimonial consensus ${ }^{97}$ and the extraordinary validation, also referred to as radical sanation (sanactio in radice), which follows under a decision of the competent ecclesiastical authority, which contains dispensation from the impediment, only if the consensus continues ${ }^{98}$. In the first case, the effects of the validation occur upon the time of reoccurrence of consensus, and in the case of the radical sanation, the effects of the canonical marriage are revoked from the moment of its contracting 99 . The basis for the radical sanation is the matrimonial consent, which had to be validly, though ineffectively, expressed and had to last at the time of its validation, because the lack of consent of even one spouse causes that marriage cannot be validated ${ }^{100}$. The ordinary validation of marriage can take place in any case, and the radical sanation in the case of impediments to marriage and failure to observe the canonical form. What is more, marriage can be validated even if one or both parties do not know of it, but only for an important reason ${ }^{101}$.

\section{CONCLUSIONS}

Annulment of marriage and declaring nullity of marriage are the institutions that function in two separate and autonomous legal systems - the state and canonical ones. Due to the fact that the canonical marriage between two baptized persons is a sacrament, it is not permissible to dissolve it by divorce or annulment. Although the grounds for annulment or declaration of nullity of marriage are similar, they should be construed taking into account the differences arising from the nature

${ }^{97}$ Can. $1156 \$ 1$; CCEO can. 843.

${ }^{98}$ Can. $1161 \$ 1$; CCEO can. $848 \$ 1$.

${ }^{99}$ Can. $1161 \$ 2$; CCEO can. $848 \$ 2$.

${ }^{100}$ Can. $1163 \$ 1$; CCEO can. 850.

${ }^{101}$ Can. 1164, can. 1156 , can. $1158 \$ 2$; can. $1159 \$ 1-2$; CCEO can. 849, can. 844-846. 
of marriage, adopted in the given legal system. The civil marriage is a contract, an agreement between the spouses, which is permanent as a rule, but it can be terminated, and in some special cases annulled. The canonical marriage between baptized persons is a sacrament, which is indissoluble by nature and causes that once validly contracted, it is terminated only upon the death of one of the spouses or dissolution under a dispensation from a contracted and not consummated marriage and the privilege of faith.

In addition, the legislator authorizes not only the spouses and the public prosecutor to claim the declaration of nullity of marriage, but also in relation to some of the impediments to marriage, any person who has a legal interest. Whereby, the ecclesiastical legislator indicates that the right to challenge the validity of the marriage is available only to the spouses and the promoter of justice. Any other person, even if they have a legal or factual interest, cannot challenge validity of the canon marriage, but only "report" it to the promoter of justice. The ecclesiastical legislator does not limit the authorization of the spouses to challenge the marriage, regardless to which party the reason for declaring nullity was attributable. Moreover, when declaring nullity of marriage, the legislator does not indicate the guilt of the spouse or to which party the bad faith was attributable, but only identifies the impediment which was the basis for declaring nullity, which applied to one or both spouses.

The list of reasons for both annulment and declaration of nullity is similar, and the differences arise from the nature of the canonical marriage. The ecclesiastical legislator provided for more impediments for termination, but in the case of the impediments which do not follow from the divine law, it allows for the possibility of dispensing from them. Similarly as in the civil law, the legislator provided for some defects to the matrimonial consent and lack of form of concluding marriage.

A significant difference between the discussed institutions is the question of validation of marriage. In the case of annulment, the legislator provides that once the reasons which are the grounds for the annulment cease to exist or after lapse of some time, convalidation follows by force of law and the right to take a legal action expires. Therefore, the status quo on the day of filing the claim is important. Only in the case of the impediment of consanguinity, validation is not possible because the relationship 
of consanguinity does not expire. In the case of the canonical marriage, the legislator provided for a special kind of validation - radical sanation, and it provides for validation even without the spouses knowing it. Nevertheless, the matrimonial consent must always exist at the time of the validation, as otherwise it is not possible. The Polish legislator provides for no requirement of duration of consensus, because the validation of is not dependent on the intention of the parties or any other person, but only on the fulfillment of the conditions provided by law.

\section{REFERENCES:}

Bartczak, Adam. 2014. „Sądowa jurysdykcja nad małżeństwem w Polsce”. Łódzkie Studia Teologiczne 23 n 2: 27-38.

Dzierżon, Ginter. 2008. „Przeszkoda uprowadzenia (kan. 1089 KPK)”. In: Matrimonium spes mundi. Małżeństwo i rodzina w prawie kanonicznym, polskim i międzynarodowym, ed. Tadeusz Płoski, Justyna Krzywkowska, 133-142. Olsztyn: Wydawnictwo UWM.

Dzierżoń, Ginter. 2006. Przeszkoda występku (kan. 1090 \$1-2 KPK), Ius Matrimoniale 11 (17): 79-89.

Dzierżoń, Ginter. 2016. „Przeszkoda wieku”. In: Przeszkody małżeńskie w prawie kanonicznym, ed. Wojciech Góralski, 67-90. Warszawa: Wydawnictwo UKSW.

Góralski, Wojciech. 2006. Kościelne prawo małżeńskie. Warszawa: Wydawnictwo UKSW.

Góralski, Wojciech. 2007. Studia nad małżeństwem i rodziną. Warszawa: Wydawnictwo UKSW.

Gręźlikowski, Janusz. 2012. „Przeszkody małżeńskie wynikające z węzła religijnego”. Prawo Kanoniczne 55 n. 2: 73-93.

Gromek, Krystyna. 2016. Kodeks rodzinny i opiekuńczy. Komentarz. Warszawa: C.H. Beck.

Ignatowicz, Jerzy, Mirosław Nazar. 2010. Prawo rodzinne, Warszawa: LexisNexis. Jancewicz, Zdzisław. 2008. Instytucja unieważnienia małżeństwa w prawie polskim. Stalowa Wola: Drukarnia Diecezjalna w Sandomierzu.

Jancewicz, Zdzisław. 2007. „Przestępstwo z artykułu 206 kk na tle wybranych zagadnień związanych z małżeństwem bigamicznym”, Kościelne Prawo Procesowe. Prawo Rodzinne. Materiały i Studia t. IV: 61-81. 
Kasprzyk, Sylwester. 2003. „Unieważnienie małżeństwa w polskim prawie rodzinnym a stwierdzenie nieważności małżeństwa w prawie kanonicznym". In: Iustitia Civitatis Fundamentum. Księga pamiątkowa ku czci Profesora Wiesława Chrzanowskiego, ed. Henryk Cioch, ks. Antoni Dębiński, Jacek Chaciński, 529-555. Lublin: Towarzystwo Naukowe KUL.

Krajewski, Radosław. 2003. Bigamia w prawie polskim i w prawie kanonicznym. Włocławek: Włocławskie Wydawnictwo Diecezjalne.

Mojak, Jan, Mirosław Nazar, Elżbieta Nezbecka. 2005. Zarys prawa cywilnego. Lublin: OW Verba.

Paździor, Stanisław. 2004. Przyczyny poważnego braku rozeznania oceniającego w świetle kan. 1095 n. 2. Lublin: Polihymnia.

Paździor, Stanisław. 2009. Przyczyny psychiczne niezdolności osoby do zawarcia małżeństwa w świetle kan. 1095 n.3. Lublin: Wydawnictwo KUL.

Piasecki, Kazimierz. 2011. „Wprowadzenie”. In: Kodeks rodzinny i opiekuńczy. Komentarz, ed. Kazimierz Piasecki, 15-38 .Warszawa: LexisNexis.

Stawniak, Henryk. 2016. „Przeszkoda niemocy płciowej”. In: Przeszkody małżeńskie w prawie kanonicznym, ed. Wojciech Góralski, 91-162. Warszawa: Wydawnictwo UKSW.

Stelmachowski, Andrzej. 1957. Przysposobienie w polskim prawie rodzinnym. Warszawa: Wydawnictwo Prawnicze.

Suchocki, Cyprian. 1997. Przeszkody małżeńskie w prawie kanonicznym i polskim kodeksie rodzinnym i opiekuńczym. Lublin-Sandomierz: Wydawnictwo Diecezjalne.

Winiarz, Jan, Janusz Gajda. 2001. Prawo rodzinne. Warszawa: LexisNexis. 
